\title{
Correction to: Computer-aided diagnosis applied to MRI images of brain tumor using cognition based modified level set and optimized ANN classifier
}

\author{
Virupakshappa $^{1} \cdot$ Basavaraj Amarapur $^{2}$
}

Published online: 3 July 2018

(C) Springer Science+Business Media, LLC, part of Springer Nature 2018

\section{Correction to: Multimed Tools Appl (2018) \\ https://doi.org/10.1007/s11042-018-6176-1}

In the original publication, equation 46 was incorrect. The original article has been corrected.

Publisher's Note Springer Nature remains neutral with regard to jurisdictional claims in published maps and institutional affiliations.

The online version of the original article can be found at https://doi.org/10.1007/s11042-018-6176-1

Virupakshappa

virupakshi.108@gmail.com

Basavaraj Amarapur

bamarapur@yahoo.com

1 Department of C S E, Appa Institute of Engineering \& Technology, Kalaburagi, Karnataka, India

2 Department of E \& E, Poojya Doddappa Appa College of Engineering, Kalaburagi, Karnataka, India 